\title{
MODELING BASED STUDY OF IMPACT LOADS GENERATED BY TORNADOES AND HURRICANES ON SAFETY-CRITICAL STRUCTURES FOR NUCLEAR STRUCTURES
}

\author{
F. M. Mohee ${ }^{1 *}$, F. M. Kamal ${ }^{2}$ M. Freire-Gormaly ${ }^{3}$ \\ ${ }^{1}$ Faculty of Applied Science and Engineering, University of Toronto, Canada \\ ${ }^{2}$ Materials Science Division, Atomic Energy Centre, Dhaka, Bangladesh \\ ${ }^{3}$ Department of Mechanical Engineering, York University, Canada \\ * faizul.mohee@utoronto.ca
}

\begin{abstract}
Safety-related buildings and structures for nuclear plants require the design and analysis of tornado and hurricane generated missile impact load. Several Canadian provinces, including Ontario, Quebec, Manitoba, Saskatchewan and Alberta are tornado prone. In Canada during the years 1980 to 2009 , a total of 1,217 tornados were observed, including one F5 scale, five F4 scale, 24 F3 scale and 119 F2 scale tornadoes. These tornadoes pose critical risks to nuclear infrastructure due to the potential for missile generated impact loads from debris present in the tornado that can impact the nuclear structures. During the years, 1918 to 2014, seven F4 scale, 18 F3 scale and 126 F2 scale tornadoes were observed in Ontario. Meanwhile, several hurricanes hit the Eastern region provinces of Canada in recent history, including Hurricane Juan in September 2003 in Nova Scotia and Prince Edward Island, and four hurricanes in Nova Scotia and New Brunswick in 1963. In this work, an ANSYS based advanced computational simulation model framework was developed to investigate the effect of the tornado and hurricane generated missile impact load on nuclear structures. The explicit dynamics module in the ANSYS software was used for simulations and the preliminary results are presented. A database of materials and potential missile impact loads were identified for future investigations. For example, concrete, reinforced concrete, steel, and reinforced concrete walls with steel liner are relevant for further study. The 0.158 meter diameter and 4.58 meter long steel pipe missiles in $103 \mathrm{~m} / \mathrm{sec}$, $89 \mathrm{~m} / \mathrm{sec}$ and $72 \mathrm{~m} / \mathrm{sec}$ maximum wind speeds were also identified for further investigation. Lab based impact loading tests on scaled down samples were also studied.
\end{abstract}

Structural Design; Impact Loading; Extreme Events; Climate Change; ANSYS

\section{INTRODUCTION}

The analysis of impact loading for nuclear structures is growing in importance given the increased number of severe and extreme weather events and storms as a result of climate change. Furthermore, the need for clean and reliable base load power from nuclear power plants for society's growing energy needs has motivated a surge in new nuclear power plant projects. Given the challenges of severe and extreme events, such as tornados, hurricanes and microbursts from thunderstorms, the in-depth analysis, characterization and modeling of impact loading from these extreme events requires further investigation. In this work, a summary of the hurricane and tornado risk in Canada, a characterization of the ranges of impact loads which require consideration and the initial development of ANSYS modeling and framework for analyzing the impact loads on nuclear power plant structures are provided.

\section{LITERATURE REVIEW}

Preliminary studies of missile impact loads for nuclear power plants have identified roadmaps for future detailed analysis on a regulatory standpoint [1], however a framework for detailed analysis in ANSYS and methods to interpret the outcomes of these analyses were not provided. Antaki [1] focused on the regulatory perspective and high-level methods of analysis. Similarly, Scheer [2] conducted extensive in depth modelling and analysis for missile impact loads from hurricanes, tornadoes and microbursts, but focused on the State of Florida and Residential and Commercial buildings instead of critical civil infrastructure such as nuclear power plants.

\section{A. Tornado Occurrence and Risk in Canada Hurricane Occurrence and Risk in Canada}

The extent of tornadoes in Canada and Ontario are outlined in the tornado maps of the respective jurisdictions provided by Environment Canada. From 1918 to 2014 more than 100 category F3-F5 tornadoes occurred in Canada (Figure 1) [3]. In Ontario from 1918 to 2004, there have been seven 'Devastating tornadoes' of severity four on the Fujita scale (F4) [3]. A 'Devastating tornado' is a F4 tornado with instantaneous wind speeds of $92.5 \mathrm{~ms}-1$ to $116 \mathrm{~ms}-1$. 
The tornado occurrences have been concentrated in the most densely populated region of Ontario, called the 'Greater Golden Horseshoe' region, with a population density of 278 people / km2 and with the largest built-up area in Canada [4]. The 'Greater Golden Horseshoe' region in Ontario has the highest risk of tornadoes. This region is also where the critical infrastructure is located, such as the Pickering Nuclear Generating Station, the Darlington Nuclear Generating Station, the transmission corridor. Civil infrastructure, such as water treatment plants, and hospitals are also located in this densely populated corridor in Ontario.

There has been an increase in the number of tornadoes recently with 95 tornadoes between 2004 and 2005 and only 105 tornadoes in the preceding ten years (1995 to 2004). In contrast, during the time period from 1918 to 1994 a total of only 526 tornadoes were recorded. Furthermore, climate change modelling shows that extreme events and storms are expected to increase in occurrence and severity [5]. Full scale modelling of thunderstorms to adequately measure wind speeds remains an area of active research [6], [7].

The area of Sitakunda is vast and so an area needed to be chosen for the research. Based on secondary data from Chemist without Borders, the area of Bariadyala was chosen for the study area (Figure 1).

A series of measurements were made of the Arsenic from the tubewells in the Bariadyala area using Hatch Kits. The Arsenic levels were above both the WHO limit and the Bangladesh limit. In the elevation map (Figure 2), the variation of concentrations is shown to be non-correlated with elevation in this specific Bariadyala area.

Mapping for finding toxic metals has been previously done for different countries. Peng et al. [33] have recently done similar mapping projects for the soils of Qatar. Peng et al.'s research [33] focused on different parameters (soil and groundwater), the mapping approach outlined here are similar.

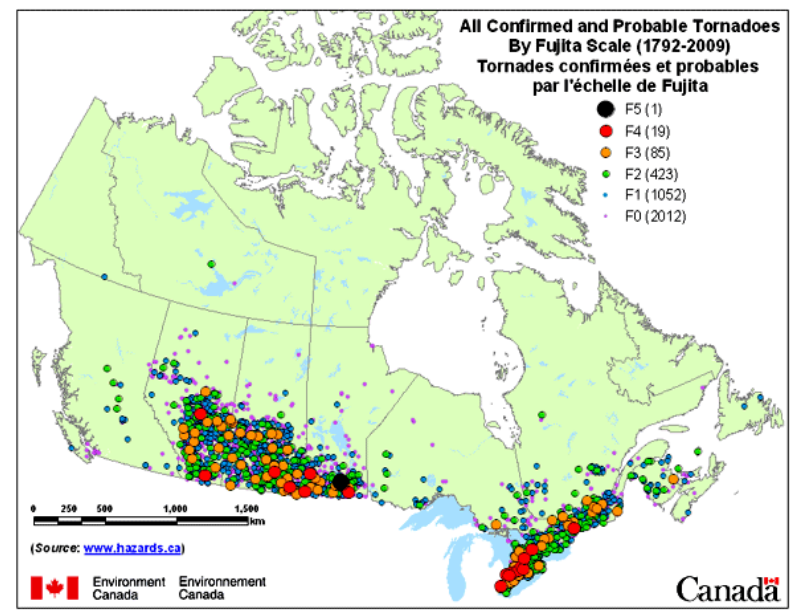

Figure 1. Hazard map of tornadoes in Canada from 1792-2009 both confirmed and probable tornadoes measured by the Fujita scale) [3].

\section{B. Hurricane Occurrence and Risk in Canada}

In Canada's history since 1900, there have been 163 hurricanes which have made landfall [8]. Most of these hurricanes have been downgraded to a post-tropical storm, since the hurricanes typically either have travelled over land for significant periods of time, or because the hurricanes have travelled large distances from tropical or warmer waters south of Canada. With climate change impacting Canada at a more drastic level than other countries, there could be an increase in the number of hurricanes which make landfall in the future [5]. The track of the hurricanes which have made landfall from 1900 to 2014 were located in Eastern Canada [8] shown in Figure 2. The most severe hurricanes that have impacted Canadian cities have been Hurricane Juan in 2003 with Category 2 winds ( $43 \mathrm{~ms}-1$ to $49 \mathrm{~ms}-1$ ) that hit the City of Halifax and caused 8 deaths; and Hurricane Hazel in 1954 with 81 deaths but it was an extra-tropical storm when it hit the City of Toronto.

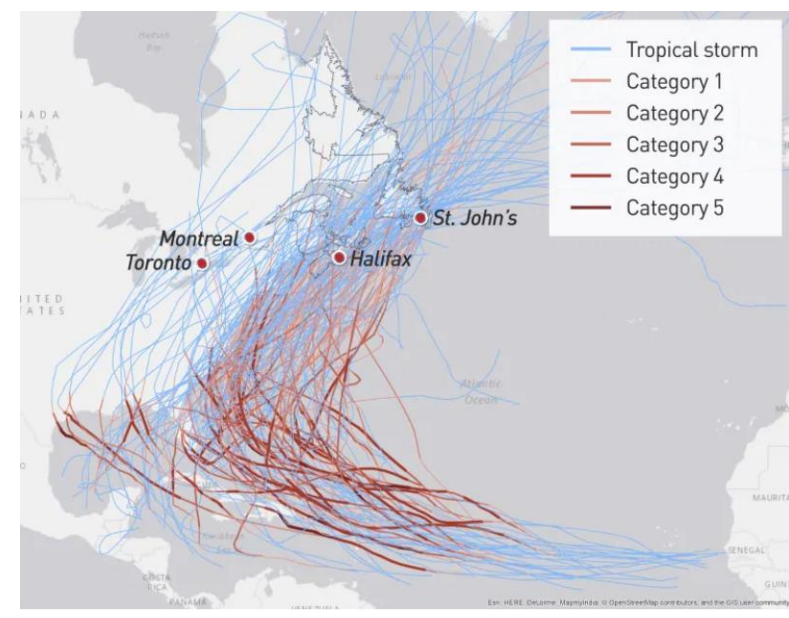

Figure 2. Tracks of the hurricanes which have made landfall in Canada (1900-2014) from data of the U. S. National Oceanic and Atmosphere Administration [8].

\section{Research Required to Mitigate Tornado and Hurricane Missile Impact Loads}

A thorough analysis of the missile impact loads from tornadoes and hurricanes are required for adequately strengthening and protecting these critical structures under the extreme loads of F4, and F3 tornadoes and Category 2 winds from hurricanes. ANSYS modelling offers a dynamic means of testing the effectiveness of concrete walls, reinforced concrete walls and concrete walls reinforced with new materials. A wide range of new materials and wind speeds require analysis.

Several new materials, such as Carbon Fibre Reinforced Polymer plates [9]-[17], Glass Fibre Reinforced Polymer and Basalt Fibre Reinforced Polymer offer a useful means of reinforcing concrete structures for nuclear power plants to more effectively withstand tornado generated missile impacts. Similarly, these new materials can also be used in Civil infrastructure including water treatment plants [18]-[22]. The design of long-term storage sites for both nuclear waste and 
carbon capture and storage technology [23]-[25], for example carbon dioxide injection well super structures could also require detailed analysis of the impact of tornado and hurricane generated impact loads. Secondary impacts on community water sources and civil infrastructure include devastating effects on spreading of industrial waste whose original source can be traced using PIXE [12].

\section{PRELIMINARY ANALYSIS}

The analysis of wind induced missile impact loads requires several steps using numerical modeling software such as ANSYS or ABAQUS. First, the development of an appropriate and representative geometry is required. As a preliminary analysis, a simple 3D wall of concrete $10 \mathrm{~m}$ in width, $10 \mathrm{~m}$ in height and $0.25 \mathrm{~m}$ in thickness is shown in Figure 3. Second, the geometry of the debris impacting the wall must be designed in the software. In this preliminary analysis, a 6-inch schedule 40 steel pipe was analyzed with a diameter of $0.158 \mathrm{~m}$ and 4.58 $\mathrm{m}$ long. This is aligned with NUREG-0800 for the analysis of missile impact loads for nuclear structures [32]. The pipe was assigned a velocity of $72 \mathrm{~ms}-1$ in Explicit Dynamics (Figure 4).

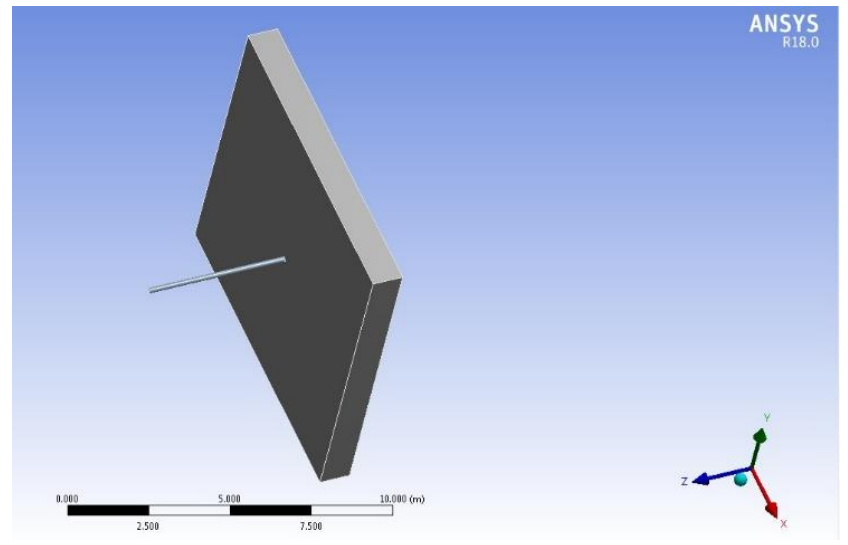

Figure 3. Initial ANSYS-based geometric model of a concrete wall impacted by a steel pipe.

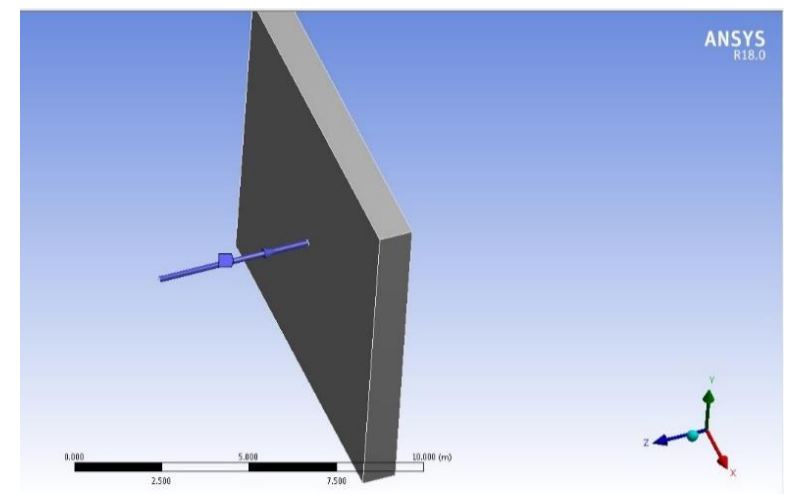

Figure 4. Diagram of Explicit Dynamics ANSYS-based analysis of a concrete structural wall being impacted at a velocity of $72 \mathrm{~ms}-1$ by a steel pipe, shown with the purple arrow overlaying the grey steel pipe.

A database of materials and potential missile impact loads were identified for future investigations (Table 1). Walls made of concrete, reinforced concrete, steel, and reinforced concrete walls with steel liner, or pre-stressed CFRP plates or GFRP rods are relevant for future investigations. The 0.158 meter diameter and 4.58 meter long steel pipe missiles in $103 \mathrm{~m} / \mathrm{sec}$, $89 \mathrm{~m} / \mathrm{sec}$ and $72 \mathrm{~m} / \mathrm{sec}$ maximum wind speeds are also useful sample tornado and hurricane generated missiles for further investigation as recommended by the NUREG-0800 for nuclear structures.

Table 1: Missile impact loads generated from tornadoes and hurricanes in ANSYS Explicit Dynamics

\begin{tabular}{lccc}
\hline & \multicolumn{3}{c}{ Wind speeds $\left(\mathrm{ms}^{-1}\right)$} \\
\cline { 2 - 4 } Materials & 1 & 2 & 3 \\
\hline $\begin{array}{l}\text { Steel Pipe } \\
(0.158 \mathrm{~m} \text { diameter, } 4.58 \mathrm{~m} \text { long, } 130 \mathrm{~kg})\end{array}$ & 72 & 89 & 103 \\
\hline $\begin{array}{l}\text { Wood Plank } \\
(0.092 \mathrm{~m} \times 0.289 \mathrm{~m} \times 3.66 \mathrm{~m}, 52 \mathrm{~kg})\end{array}$ & 66 & 83 & 97 \\
\hline $\begin{array}{l}\text { Automobile } \\
(5 \mathrm{~m} \times 2 \mathrm{~m} \times 1.3 \mathrm{~m}, 1810 \mathrm{~kg})\end{array}$ & 59 & 52 & 41 \\
\hline
\end{tabular}

\section{CONCLUSIONS}

The risk hazards of tornadoes, hurricanes and increased severity of thunderstorms and microbursts from climate change necessitate a renewed effort to modeling and analyzing the impact tornado and wind generated missile loads on structures. Future studies are required to systematically analyze the damage missile loads generated by debris flying at high wind speeds can have on critical infrastructure such as nuclear plants, water treatment plants and hospital buildings. As well, these future studies should thoroughly investigate the role new materials such as Carbon Fibre Reinforced Polymer plate reinforcement in concrete walls can play to mitigate the risks posed by tornado and hurricane generated missiles.

\section{ACKNOWLEDGMENT}

The authors are thankful to the Natural Sciences and Engineering Research Council (NSERC) of Canada for the NSERC Discovery Grant and the AECB.

\section{REFERENCES}

[1] Antaki, G. 2016. Tornado missile design for nuclear power plants. In U.S. Dept of Energy Natural Phenomena Hazards Meeting (pp. 1-18).

[2] Freire-Gormaly, M. 2013. The Pore Structure of Indiana Limestone and Pink Dolomite for the Modeling of Carbon Dioxide in Geologic Carbonate Rock Formations. University of Toronto. Retrieved from http://hdl.handle.net/1807/42840

[3] Freire-Gormaly, M. 2018. Experimental Characterization of Membrane Fouling under Intermittent Operation and Its Application to the Optimization of Solar Photovoltaic Powered Reverse Osmosis Drinking Water Treatment Systems. University of Toronto.

[4] Freire-Gormaly, M, Bazylak, A., \& Maclean, H.L. 2012. Microct Investigations and pore network reconstructions of limestone and carbonate-based rocks for deep geologic carbon sequestration, ASME 2012 6th International Conference on Energy Sustainability collocated with the ASME 2012 10th International Conference on Fuel Cell Science, Engineering and Technology, American Society of Mechanical Engineers, pp. 863-866. 
[5] Freire-Gormaly, M., Ellis, J. S., Bazylak, A., \& Maclean, H.L. 2012. Pore Network Reconstructions and Pore-Scale Characterization of Limestone and Carbonate-Based Rocks for Deep Geologic Carbon Sequestration. In 223rd ECS Meeting, 157.

[6] Freire-Gormaly, M., Ellis, J. S., Bazylak, A., \& MacLean, H. L. 2015. Comparing thresholding techniques for quantifying the dual porosity of Indiana Limestone and Pink Dolomite. Microporous and Mesoporous Materials, 207, 84-89. https://doi.org/10.1016/j.micromeso.2015.01.002

[7] Hess, P., Sorensen, A., \& Parizeau, K. 2007. Urban Density in the Greater Golden Horseshoe. Toronto. Retrieved from http://www.urbancentre.utoronto.ca/pdfs/publications/RP209_Hess_et al_May_2007.pdf

[8] Hoque, A., Kamal, F., Mohee, F. M., Haque, M., \& Hossain, M. (2007). Fluoride, Magnesium, and Sodium in dental chewing stick plants used in Bangladesh. Fluoride, 40(1), 24-30.

[9] Kamal, F., Ahmed, N., Mohee, F. M., Abedin, M., Shariff, A., Saadat, A., \& Hoque, A. (2007). Trace element analysis in soil samples of Hazaribagh tannery area by PIXE. Journal of Environmental Science, 5, 31-36.

[10] Masson-Delmotte, V., P. Zhai, H.-O. Pörtner, D. Roberts, J. Skea, P. R. S., A. Pirani, W. Moufouma-Okia, C. Péan, R. Pidcock, S. Connors, J.B.R. Matthews, Y. Chen, X. Zhou, M. I. G., \& E. Lonnoy, T. Maycock, M. Tignor, and T. W. 2018. Summary for Policymakers on Global Warming of $1.5^{\circ} \mathrm{C}$. An IPCC Special Report on the impacts of global warming of $1.5^{\circ} \mathrm{C}$ above pre-industrial levels and related global greenhouse gas emission pathways, in the context of strengthening the global response to t. Retrieved from https://www.ipcc.ch/site/assets/uploads/sites/2/2019/05/SR15_SPM_vers ion_report_LR.pdf

[11] Mohee, F., Al-Mayah, A., \& Plumtree, A. 2016. Friction Characteristics of CFRP Plates in Contact with Copper Plates under High Contact Pressure. Journal of Composites for Construction, 4016022. https://doi.org/10.1061/(ASCE)CC.1943-5614.0000673

[12] Mohee, F. M. 2017. Development, Analysis and Testing of Innovative Mechanical Prestressing Anchors for CFRP Plates for Structural Rehabilitation and Retrofitting. University of Waterloo (UWSpace). Retrieved from http://hdl.handle.net/10012/11207

[13] Mohee, F. M., \& Al-mayah, A. 2017. Effect of modulus of elasticity and thickness of the CFRP plate on the performance of a novel anchor for structural retrofitting and rehabilitation applications. Engineering Structures, $\quad 153, \quad 302-316$. https://doi.org/10.1016/j.engstruct.2017.09.057

[14] Mohee, F. M., \& Al-Mayah, A. 2017. Development of an innovative prestressing CFRP plate anchor: Numerical modelling and parametric study. Composite $\quad$ Structures, 177, 1-12. https://doi.org/10.1016/j.compstruct.2016.12.039

[15] Mohee, F. M., \& Al-Mayah, A. 2018. Effect of barrel, wedge material and thickness on composite plate anchor performance through analytical, finite element, experimental and 3D prototype investigations. Engineering Structures, 175, 138-154.

[16] Mohee, F. M., Al-Mayah, A. 2017. Towards A Mechanical Anchor System For CFRP Plates, Canadian Society of Civil Engineers (CSCE) 2017 Annual Conference, Vancouver, Canada.

[17] Mohee, F. M., Al-Mayah, A., \& Plumtree, A. 2016. Anchors for CFRP plates: State-of-the-art review and future potential. Composites Part B: Engineering, $\quad 90, \quad 432-442$. https://doi.org/10.1016/j.compositesb.2016.01.011

[18] Mohee, F. M., Al-Mayah, A., \& Plumtree, A. 2017. Development of a novel prestressing anchor for CFRP plates: Experimental investigations. Composite Structures, 20-32. https://doi.org/10.1016/j.compstruct.2017.05.011

[19] Mohee, F. M. 2016. The Effects of Strain Rate on Concrete Strength under Dynamic Impact Load, Journal of Bangladesh Electronics Society, 16.

[20] Mohee, F. M. \& Kamal, F. M. 2017. Ground Response Spectra for Different Damping Values for 0.3g Peak Ground Acceleration Earthquake in Bangladesh, Journal of Bangladesh Electronics Society, 17.
[21] Mohee, F. M. \& Kamal, F. M. 2017. Application of High-strength Composite Materials for the Nuclear Waste Containers and Flasks, Canadian Society of Civil Engineers (CSCE) 2017 Annual Conference, Vancouver, Canada.

[22] Mohee, F. M. \& Kamal, F. M. 2016. Manufacturing of Nuclear Waste Containers and Flasks: Consideration of Transportation Load, Acceleration Load and Fatigue Load: a Structural Engineering Perspective, 36th Annual Conference of the Canadian Nuclear Society 40th Annual CNS/CNA Student Conference, 2016 June 19 - 22, Marriott Toronto Eaton Centre Hotel, Toronto, Canada.

[23] Mohee, F. M. 2013. A review of the Effects and Control of the Mercury Emissions from Cement industry, EIC - Climate Change Technology Conference 2013, Montreal, Canada

[24] Mohee, F. M., \& Miller, C. 2010. Climatology of thunderstorms for North Dakota, 2002-06. Journal of Applied Meteorology and Climatology, 49(9), 1881-1890. https://doi.org/10.1175/2010JAMC2400.1

[25] Mohee, F. M. 2019. Usage of Radar reflectivity data and Surface speed data for the prediction of climate change patterns in Bangladesh, International Conference on Climate Change Impacts and Adaptation Strategies for Bangladesh.

[26] Mohee, F. M. 2008. Development of a radar based thunderstorm climatology for North Dakota, 24th Conference on Severe Local Storms, American Meteorological Society (AMS), GA, USA. Retrieved from https://ams.confex.com/ams/24SLS/techprogram/paper_142135.htm

[27] NUREG-0800. 2010. U.S. Nuclear Regulatory Commission Standard Other Seismic Category I Structures. USA.

[28] Rocha, R. 2017. These are all the hurricanes that hit Canada since 1900. Retrieved May 23, 2019, from https://www.cbc.ca/news/canada/montreal/hurricane-history-canada1.4284076

[29] Scheer, D. L. 2005. Large Wind Missile Impact Performance of Public and Commercial Building Assemblies. Florida State University. Retrieved from https://diginole.lib.fsu.edu/islandora/object/fsu:180298/datastream/PDF/ view

[30] Sills, D. 2009. Tornado Hazard Maps. Retrieved from http://www.aceracre.ca/publications-and-research/research/tornado

[31] Solari, G. 2014. Thunderstorm Monitoring, Modelling, Response and Loading of Structures. Wind Engineering, JAWE, 39(4), 344-346. Retrieved from https://www.jstage.jst.go.jp/article/jawe/39/4/39_344/_pdf/-char/en 